Journal of Health Promotion and Behaviour (2016), 1(4): 224-228

https://doi.org/10.26911/thejhpb.2016.01.04.01

\title{
The Effect of Self Help Group on Knowledge and Attitude in Decision Making Among Household Head of Patients with Depression in Yogyakarta
}

\author{
Endang Tri Sulistyowati'), Bhisma Murti²), Yulia Lanti Retno Dewi3) \\ 1)Health Academy of Karya Husada, Yogyakarta \\ 2)Masters Program in Public Health, Universitas Sebelas Maret, Surakarta \\ 3)Faculty of Medicine, Universitas Sebelas Maret, Surakarta
}

\begin{abstract}
Background: Treatment of patients with mental health problem at home and hospital has been so variable and unsatisfactory. An often assumed causal factor of this problem is lack of knowledge among household heads of patients with mental health problem. This study aimed to determine the effect of self help group on knowledge and attitude in decision making among household heads of patients with depression in Yogyakarta.

Subjects and Method: This was an analytic experimental study with RCT (Randomized Control Trial). This study was conducted at Jetis, Sleman, Yogyakarta. Study subjects included household heads and 60 patients with depression. The dependent variables were knowldege and attitude in decision making. The independent variable was self health group. The data were collected by use of a set of questionnaire. The data were analyzed by logistic regression.

Results: There was positive relationship between engaged in self help group and knowledge (OR= 1.46, 95\% CI=1.33-14.02, $\mathrm{p}=0.015$ ) among household heads of patients with depression. There was positive relationship between being engaged in self help group and attitude, but it was statistically non-significant $(\mathrm{OR}=1.46,95 \% \mathrm{CI}=0.74-25.41, \mathrm{p}=0.105)$.

Conclusion: Self help group has positive significant effect on household head's knowledge, as well as attitude in decision making among household heads.
\end{abstract}

Keywords: self help group, knowledge, attitude

\section{Correspondence:}

Endang Tri Sulistyowati. Health Academy of Karya Husada, Yogyakarta. Email: endangts8o@gmail.com.

\section{BACKGROUND}

Depression is a disorder that can interfere with everyone's life regardless of biological, psychological, or social aspects. Depression can occur without us knowing it. Sometimes, depression sufferers are late in getting help, which results in worse things. Depression can be caused by the interaction of self-pressure and mental resistance to the environment. The World Health Organization (WHO) stated that depression disorders ranks fourth in the world with women experiencing depression by $20 \%$ and men by $12 \%$ at a time in life. It is estimated that the number of sufferers of depression in 2000 is increasing and will occupy the second rank of diseases in the world (Muchid et al., 2007).

Every year, mental health problems increase significantly. Basic Health Research in 2007 explained that in Indonesia the prevalence of emotional problems was 24.3 million people. Whereas, in 2013, the number of people with mental health problem reached 1.7 million, the high number of mental health problem indicated that individuals experience an emotional change that if not handled properly can develop into pathology. 
Based on the results of a survey and interview in January 2016 at Jetis, Yogyakarta, it was found that knowledge and attitudes of household heads about mental health problem were still low due to the lack of mental health education. Many household heads consider that mental disorders are a shameful disease, disgrace, and a frightening specter. So, they decided to send family members mental health problems to a hospital outside their area.

The purpose of this study was to determine whether the influence of self help groups can improve the knowledge and attitudes of the head of the family in making decisions in sufferers of depression.

SUBJECTS AND METHOD
This study used an experimental analytical
design with Randomized controlled trial
(RCT) design, where the grouping of
subjects of the study in the intervention
group and the control group was done
randomly. The sample selection technique
used was simple random sampling tech-
nique, the sample used was all household
heads who met the inclusion criteria.
The calculation of the subject of this
study used the "rule of thumb" which was a
subject of the study of at least 30 people for
each group (Murti, 2013). With rando-
mization, only the opportunity factors that
determine the subject of the study would be
selected into the experimental group or the
control group. The intervention provided
was in the form of a self-help group in the
intervention group and mental health edu-
cation in the control group. Data analysis
used was logistic regression analysis.
The instrument of the study used was
questionnaires. Measuring the knowledge
of the household head was done by filling in
20 questions. If the score obtained was $75 \%$

$-100 \%$, the knowledge of the household head was good. Knowledge of the household head was sufficient if the score obtained was $50 \%-75 \%$, and knowledge was lacking if the score was less than $50 \%$. While, measuring the attitude of the household head was done by filling in 20 questions consisting of favorable and nonfavorable questions. Score $>60 \%=$ good attitude and score $<60 \%=$ bad attitude.

\section{RESULTS}

The characteristics of the subjects of the study included gender, age and level of education. The subjects of this study were categorized into 2 groups, namely Self Help Group group as many as 30 people and non Self Help Group as many as 30 people.

Table 1 shows the results of the frequency distribution of the characteristics of the subjects of the study. Table 1 shows that all subjects of the study were male (100\%). Most of the subjects of the study had an average age of 46-55 years as many as 29 people (48.3\%), and had a high school education level as many as 31 people (51.7\%).

The results of the chi squre test on the effect of self help groups on the knowledge of household heads can be seen in Table 2 .

Table 2 shows that the majority of the subjects of the study in the non Self Help Group group had knowledge at a moderate levelas many as 12 people (40.0\%) and in the Self Help Group group after being given the Self Help Group most of them had good knowledge of 20 people (66.7\%). The subjects of the study who were given Self Help Group had 4 times better knowledge than the group that was not given Self Help Group as evidenced by value $\mathrm{OR}=4.00 \mathrm{CI}$ 95\% $1.37-11.7 \%$. 
Journal of Health Promotion and Behaviour (2016), 1(4): 224-228

https://doi.org/10.26911/thejhpb.2016.01.04.01

Table 1. The Frequency distribution of characteristics of the subjects of the study

\begin{tabular}{lcc}
\hline \multicolumn{1}{c}{ Characteristics } & Frequency & \% \\
\hline Gender & 60 & 100 \\
Male & & \\
Age & 19 & 31.7 \\
$36-46$ years & 29 & 48.3 \\
$46-55$ years & 12 & 20.0 \\
$56-65$ years & & \\
Education & 8 & 13.3 \\
Elementary School & 16 & 26.7 \\
Junior High School & 31 & 51.7 \\
Senior High School & 5 & 5.3 \\
University & & \\
\hline
\end{tabular}

The results of the test showed a significant $\mathrm{p}$ of 0.010 , so there was an effect of Self Help Group on knowledge in household heads' decision making with proven Table 2. The results of chi square test on the effect of self help group on knowledge

\begin{tabular}{|c|c|c|c|c|c|c|c|c|c|c|}
\hline \multirow{3}{*}{$\begin{array}{l}\text { Self Help } \\
\text { Group }\end{array}$} & \multicolumn{6}{|c|}{ Knowledge } & \multirow{3}{*}{ OR } & \multicolumn{2}{|c|}{$95 \%$ CI } & \multirow{3}{*}{$\mathbf{p}$} \\
\hline & \multicolumn{2}{|c|}{ Poor } & \multicolumn{2}{|c|}{ Enough } & \multicolumn{2}{|c|}{ Good } & & Lower & Upper & \\
\hline & $\mathbf{n}$ & $\%$ & $\mathbf{n}$ & $\%$ & $\mathbf{n}$ & $\%$ & & limit & limit & \\
\hline $\begin{array}{l}\text { Non Self Help } \\
\text { Group }\end{array}$ & 8 & 26.2 & 12 & 40 & 10 & $33 \cdot 3$ & 4.00 & 1.37 & 11.70 & 0.010 \\
\hline Self Help Group & 3 & 10 & 7 & 23.3 & 66.7 & 30 & & & & \\
\hline
\end{tabular}

Based on Table 3, the majority of subjects of the study in the non Self Help Group had a good attitude as many as 20 people (66.7\%) and in Self Help Group group also had a good attitude as many as depression sufferers. The results of the chi squre test about the effect of Self Help Group on the attitudes of household heads can be seen in Table 3 .

Table 3. The results of chi square test about the effect of self help group on the household head's attitude

\begin{tabular}{|c|c|c|c|c|c|c|c|c|}
\hline \multirow[b]{2}{*}{ Self Help Group } & \multicolumn{4}{|c|}{ Attitude } & \multirow[t]{2}{*}{ OR } & \multicolumn{2}{|c|}{ CI 95\% } & $\bar{p}$ \\
\hline & Bad & $\%$ & Good & $\%$ & & $\begin{array}{l}\text { Lower } \\
\text { limit }\end{array}$ & $\begin{array}{l}\text { Upper } \\
\text { limit }\end{array}$ & \\
\hline $\begin{array}{l}\text { Non Self Help Group } \\
\text { Self Help Group }\end{array}$ & $\begin{array}{l}10 \\
2\end{array}$ & $\begin{array}{l}33 \cdot 3 \\
6.7\end{array}$ & $\begin{array}{l}20 \\
28\end{array}$ & $\begin{array}{l}66.7 \\
93.3\end{array}$ & 7.00 & 1.38 & 35.48 & 0.010 \\
\hline
\end{tabular}

\section{DISCUSSION}

\section{Gender}

Based on the results of cross tabulation, the subject of the study in the Self Help Group and non Self Help Group showed that were male (100\%). This is still in accordance with the prevailing norms in the commu-
28 people (93.3\%). Subjects of the study who were given Self Help Group have 7 times better than groups that were not given the Self Help Group. 
powers that are dominant compared to women. In some customs of the community in Indonesia, the application of patriarchal culture still often encountered, which emphasizes the power of men both to make decisions and determine all family affairs.

\section{Age}

Most household heads in the non Self Help Group and Self Help Group groups who live in Jetis as the subjects of the study were included in the category of early elderly (46-55 years) by $48.3 \%$ of the total sample.

The conditions above indicate that the subjects of the study used were mostly still able and willing to fill out questionnaires and become the subject of the study. The findings of this study are at least in line with the results of the study of Seif et al., (2010), which stated that older people have a better and broader level of knowledge. A person's age affects the amount of experience and information.

\section{Education}

The results showed that the majority of the research subjects had high school education levels of $(51.7 \%)$. From the conditions above, it can be explained that the research subjects had a high level of education. When associated with research conducted by Marta (2001), states that the higher a person's education the easier the person receives information.

This study concludes that Self Help Group has a positive effect on the knowledge of the head of the family and statistically significant as evidenced by $(\mathrm{OR}=$ 4.00; 95\% CI= 1.37-11.70; $\mathrm{p}=0.010$ ) and the Self Help Group positively influences the attitude of the head of the family and statistically significant as evidenced by (OR = 7.00; $95 \% \mathrm{CI}=1.38-35.48 ; \mathrm{p}=0.010$ ).

\section{REFERENCE}

$\overline{\text { Badan penelitian dan pengembangan kese- }}$ hatan Depkes RI (2014). Riset Kese- hatan Dasar 2013. http://www Riset Kesehatan Dasar 2013.Pdf Retrieved March 10, 2016

Chien WT, Chan SWC, Thompson DR (2006). Effect of a mutual support group for families of chinese people with schizoprenia: 18 Friedman.

MM (2010). Keperawatan Keluarga: Teori dan praktek: alih bahasa, Ina Debora: editor Yasmin. Edisi 3. Jakarta: EGC

Hunt (2004). A resource kit for selg help/support groups for people affecctedby eating disorder. http://www.medhelp. org/njgroupe/volunteerGuide.pdf.

Retrieved April 4, 2016

Juliansyah (2010). Peran Keluarga Menangani Penderita Gangguan Jiwa.http://www.pontianak.com/file/new portal.htm.

Jorm A (2011). Public Knowledge and beliefs about mental disorder. British Journal of Psychiatry.http://bjp.rcpsych.org/content/177/5/396.full.pdf. Retrieved March, 102011

Keliat (2006). Peran serta Keluarga dalam Perawatan klien Gangguan Jiwa. Jakarta: EGC

Keliat BA (2011). Menanti Empati terhadap Orang dengan Gangguan Jiwa. Pusat Kajian dan Tindak Kekerasan Departemen Psikiatri FKUI-RSCM, Jakarta

Maslim R (2002). Gejala Depresi Diagnosa Gangguan Jiwa. Rujukan dari PPDGJ. III. Jakarta: FK Unika Atmajaya, 5865

Muchid (2007). Pharmaceutical care untuk penderita gangguan depresi. Jakarta : Direktorat Bina Farmasi Komunitas dan klinik Depkes RI

Murti B (2013). Desain dan Ukuran Sampel untuk Penelitian Kuantitatif dan Kualitatif di Bidang Kesehatan. Yogyakarta: Gadjah Mada University Press 
Journal of Health Promotion and Behaviour (2016), 1(4): 224-228

https://doi.org/10.26911/thejhpb.2016.01.04.01

National Institude of Mental Health (2008). Depression. NIH publications. Available form http://www.nihm .nih.gov/health/publication/depressi on/nimhdepression.pdf. Retrieved April 2016

Reigh LSM, Preston CHK (2006). Spiritual care. Practical guidelines for rehabilitationnurses.http://Proquest.Umi.c om/pgdweb. Retrieved Maret 11, 2016

Suryani Luh Ketut (2005).Faktor-faktor Penyebab Timbulnya Gangguan Ji-
wa.http://www.bali.co.id/Bali/2005/ 8/3/K4.

Townsend MC (2003). Psychiatric Mental Health Nursing:consept of care Philadelphia:Davis company

Videbeck SL (2008). Buku Ajar Keperawatan Jiwa. Jakarta: EGC

WHO (2005). Kesehatan Mental, Hak Asasi dan Legislasi edisi Khusus tentang Kesehatan Mental.

Yosep (2010). Keperawatan Jiwa. Bandung Refika Aditama. 